\title{
Holocaust and WWII: Jews in the Red Army
}

\author{
Gabriel Mayer $^{1}$ \\ ${ }^{1}$ University of Haifa- International School for Holocaust Studies, Israel. \\ Correspondence: Gabriel Mayer, University of Haifa- International School for Holocaust Studies, Israel.
}

Received: February 9, 2015

Accepted: February 26, 2015

Available online: February 27, 2015

doi:10.11114/ijsss.v3i2.668

URL: http://dx.doi.org/10.11114/ijsss.v3i2.668

\begin{abstract}
This paper focuses on the role of Jews in the Red Army in general and during WWII in particular. Historians estimate that a relatively high number of Jews (1.5 to 1.7 million) fought in the combined Allied Forces during WWII. At the same time, the fact that about 500,000 Jews enlisted or were conscripted into the Red Army has been largely ignored. After the demise of Communist regimes in the 1990s, however, the role of Jews serving in the Red Army began to be mentioned in cultural narratives. Today, especially in Israel, the increased focus on Jewish identity is often rooted in military and armed resistance during WWII. One author has termed this cultural phenomenon as "the migrating past." Citing examples from established scholarship and examining some previously unpublished documents, this paper sheds light on the heroic aspect of Jewish history during the war. This aspect of heroism, which has not always been recognized, today has moved into the mainstream cultural narrative of Russian Jews, affecting their Jewish identity.
\end{abstract}

Keywords: Holocaust; WWII, Jews Red Army, Jewish Resistance, Jewish Heroism, Jews Fighting WWII

\section{Background}

An often-heard refrain describing the behavior of Jews during the Holocaust is that "they did not fight back." The notion that Jews went like "lambs to the slaughter," ${ }^{2}$ and similar misconceptions, have dominated much of post-WWII discourse in the West and even in Israel. Jewish heroism has been reduced to the Warsaw Ghetto uprising and other armed resistance, mostly in the ghettos or camps. The reality is much more complex.

\subsection{Review of Scholarship}

It has been documented that $500,000^{3}$ Jews fought in the Red Army during WWII, and that the total numbers of Jews fighting in WWII amounted to approximately 1.7 million ${ }^{4}$ out of a worldwide population of less than 16 million, in other words, more than $10 \%$ of the worldwide Jewish population. Nevertheless, the earliest (and for a long time the only) recognition of Jewish participation in military operations was of Jewish GIs discussed in the American press. ${ }^{5}$

This paper draws on scholarship accessible in the FSU and presents materials showing that even before the Soviet statistics became available, after the fall of Communism, certain visible activities could point to the participation of Jews in WWII in the ranks of the Red Army. For example, Der Spiegel and other newspapers published articles on clubs and associations of Jewish veterans in many parts of the world, including the USSR. ${ }^{6}$ The bulk of Western scholarship, however, largely ignored this information, and the question of why this happened deserves attention.

\footnotetext{
1 (Roberman 2007, p. 1035)

2 (Porat 2009, pp 62-70) Abba Kovner in the Vilna Ghetto in his manifesto exhorting Jews to fight first used this expression, destined to become a pejorative regarding Jewish victimhood. Thus, even this one phrase, long used with a negative connotation, turns out to be rooted in resistance and a call to fight back.

3 (Gitelman 1990) (Arad 2010) (Gitelman 2001). These and many other sources provide roughly the same numbers.

4 This number is quoted from Dr. David Silberklang's lecture at Haifa University, July 20, 2014. The figure of 1.5 million is provided by Roberman (Roberman 2009, p. 30).

5 (Davis 1945, Kaufman 1947). These early works, and much of what was written for several decades, account only for American Jewish soldiers.

6 (Sontheimer 2005).
} 
At the end of this paper I present several personal stories of Jewish combatants, some of them based on unpublished, primary sources.

\section{Brief Overview of Jews in the Red Army}

Since 1827, when Emperor Nicholas I issued his "Statute on Conscription Duty" to counteract the "buy out" practices previously in use, ${ }^{7}$ Jewish men were subject to conscription into the Russian army. The census of 1926 shows that under early Soviet rule the ratio of Jews in the Red Army was $24 \%$ higher than in the general population. ${ }^{8}$ The ratio for the officer corps was even more disproportionate, a fact that may be explained by the generally higher level of education of Jews than that of their Russian peers. ' During the upheavals referred to as "Stalin's reign of terror," in 1937-1938, about 700,000 members of the high-ranking military and political establishment in the USSR were executed on direct orders from Stalin, ${ }^{10}$ including many members of the Jewish elite. There is no indication, however, that this persecution can be attributed to their Jewishness as opposed to their position in the system. ${ }^{11}$ At the same time, the military careers of a considerable number of high-ranking Jewish officers continued throughout WWII, and many even survived post-war purges in the army.

\section{Jews in the Red Army during WWII}

With the outbreak of WWII, the disproportionate representation of Jews in the Red Army increased even further, as did the ratio of promotions and decorations awarded to Jewish combatants. The following numbers illustrate the recruitment of Jews, as volunteers and conscripts, in large population centers: ${ }^{12}$ Moscow - 140,000 (population of 5 million); Leningrad - 130,000 (population of 3.2 million); Odessa - 55,000 (population of 604,000); Kiev - 35,000 (population of 846,000). In certain military units, such as the Latvian Division, where Jewish soldiers constituted 30\%, the numbers are even more disproportionate. ${ }^{13}$ The motivation of the Jews to fight was clearly fueled also by the news of the destruction of Jewry at the hands of the Nazis. This circumstance did not escape the attention of the political leadership of the Red Army (GPUKA), which stated, "the most loyal elements in the Red Army during this difficult phase of the war were mostly Russians defending the homeland ("Mother Russia") and Jewish soldiers." 14 The special motivation of the Jews prompted a suggestion to form Jewish fighting units. Thus, on February 12, 1943, Abram Margolis, the Commissar of the 32nd Infantry Division, called for the formation of a Jewish division, in light of the singularly horrific suffering that Jews were experiencing at the hands of the Nazis. ${ }^{15}$

Numbers alone do not tell the full story, however. During WWII, Jewish soldiers attained high ranks and received prestigious decorations. In Lithuania, the following Jewish generals participated in and commanded units during some of the most arduous phases of the war: General and Commander Izrail Borskin of the 65th Army, General Grigori Plaskov of the 2nd Armored Corps, and General Moise Kharkovsy of the 12th Artillery. These generals and scores of other Jewish soldiers received "Order of Lenin" decorations. ${ }^{16}$ Altogether, during the 1940-1945 period, a total of 229 Jews were promoted to the rank of General or Admiral. ${ }^{17}$ The ranks of the decorated soldiers and officers were entirely out of proportion with the percentage of Jews in the population at large or even in the armed forces: in absolute terms, Jews accounted for the fourth largest number of highly decorated soldiers by nationality, following Russians, Ukrainians, and Belarusians, but naturally, out of a far smaller population. ${ }^{18}$ The highest military honor, "Hero of the Soviet Union," was accorded to 154 Jews. ${ }^{19}$ A telling detail of this remarkable saga is that on January 31, 1943, at

\footnotetext{
7 (Hundert 2008).

8 (Altshuler 1998, pp. 19).

9 (Altshuler 1998, pp. 156-59).

10 (Snyder 2012). Snyder cites the "reign of terror" as one of six great exterminations occurring in the mid-20th century, placing it in on a par with the Holodomor, the Holocaust, and three other episodes surrounding WWII.

11 (Asher 2003, pp 886-89).

12 (Arad 2010, pp. 19).

13 Ibid (pp. 7).

14 Ibid (pp. 23).

15 Ibid (pp. 10)

${ }^{16}$ Ibid (pp.59-60).

17 (Altshuler 1998, pp. 156).

18 (Arad 2010, pp. 24).

19 Ibid (pp. 24).
} 
Stalingrad, General von Paulus, Commander of the German 6th Army, surrendered to Lt. Colonel Leonid Vinoukur, a Jew. ${ }^{20}$

An insight into the combination of luck and opportunity for a Jew under Communism, confronted with WWII, can be gleaned from Catherine Merridale's interview with Kirril Kirrilovich, in her book, Ivan's War. ${ }^{21}$ Kirill hailed from Belarus and happened to land in Moscow when war broke out. He also just happened to have a friend whose father was a high-ranking Commissar. The combination of war and soldiering opened up educational opportunities, all of which he availed himself of. Thus, this young Jew, unlike that the rest of Dubrovnov's Jews, driven like cattle into the town square, in 1941, and burned or shot, survived and prospered. He remained a lifelong admirer of Comrade Stalin.

After WWII, the fortunes of Jewish soldiers in the Red Army vary. Some officers made a lifetime career in the armed forces and continued successfully during several phases of Stalin's rule and through successive purges and reshufflings of the higher ranks. General Yakov Kreyzer was the highest-ranking Jew in the Red Army. He was a Colonel General and Army Commander who remained in the military and subsequently held several important government positions, until his death in 1961, and was buried with full honors. Colonel Isaac Graifer, whose story appears at the end of this article, had a similar path of success before, during, and after WWII. Many Jews found that acquiring higher education before joining the military, or alternatively, using the opportunity to acquire education while serving, made them ideally suited for a military career. A rich accounting of specific individuals appears in a detailed work by Reuben Ainsztein, ${ }^{22}$ where we learn, among others, that Matrosov's legendary feat of blocking a German machine gun with his body to allow his comrades to advance was repeated by Yosif Bumagin in Breslau, Poland, and in the Battle of Moscow by Yakov Paderin, both Jews. ${ }^{23}$

Despite the ability of several Jewish officers to maintain their careers in the military after WWII, the anti-Semitism that Stalin incited after the war affected all Jews in the post-WWII USSR, including those in the military. The story that best epitomizes the treatment of the Jews in the USSR after the war is that of the "Unknown Black Book" 24 and of the "tragic legacy of the Jewish Anti-Fascist Committee (JAC)." 25 JAC was established during the war and enlisted some of the most brilliant Jewish minds in literature and the arts to record the Nazi atrocities and serve the Soviet propaganda in its efforts to raise funds for the war in the West, primarily in the US and in England. The results were excellent, and many portions of the records thus collected found their way overseas. As the war came to an end, however, there was no longer a need to evoke sympathy for particular groups, especially not for the Jews. ${ }^{26}$ Therefore, the effort to produce the "Black Book" and bring it to the West ran afoul of official policy. Portions of the manuscript made their way to New York, where the "Black Book" was published in 1946. But no Russian edition appeared and one by one the Jewish activists were executed. The leader of the JAC, Solomon Mikhoels, was murdered in a staged car accident in 1948.

\section{History, Scholarship and Culture}

In answer to a question about why it has taken so long to reveal the full stories of Jews in the Red Army, Professor Dina Porat reflected that although the data and facts existed, they were never contextualized as part of Jewish history, until the first wave of publications in the 1970s, and the subsequent expansion of scholarship, especially when access to the archives became available after the fall of Communism. ${ }^{27}$ Note that in general, under Soviet rule, WWII held a special place in reality, history, and scholarship. Any attempt to single out a national group for attention was resisted. Altshuler wrote the definite article on the subject: "Jewish Holocaust Commemoration in the USSR under Stalin." In 1992, Edith Clowes wrote that "Indeed until recently, Soviet literature on the extermination of the Jews has deliberately been unwilling to distinguish the Holocaust from unichtozhenie (annihilation) and katastrofa (catastrophe) as these were applied to the general Russian experience, and omitted any uniquely Jewish aspect of the Nazi Final Solution."28

The change in the attitude of historiography and scholarship followed developments on the ground. Professor Porat recounts the appearance of Jewish Soviet war veterans at rallies and meetings in Israel, bedecked with a chest full of

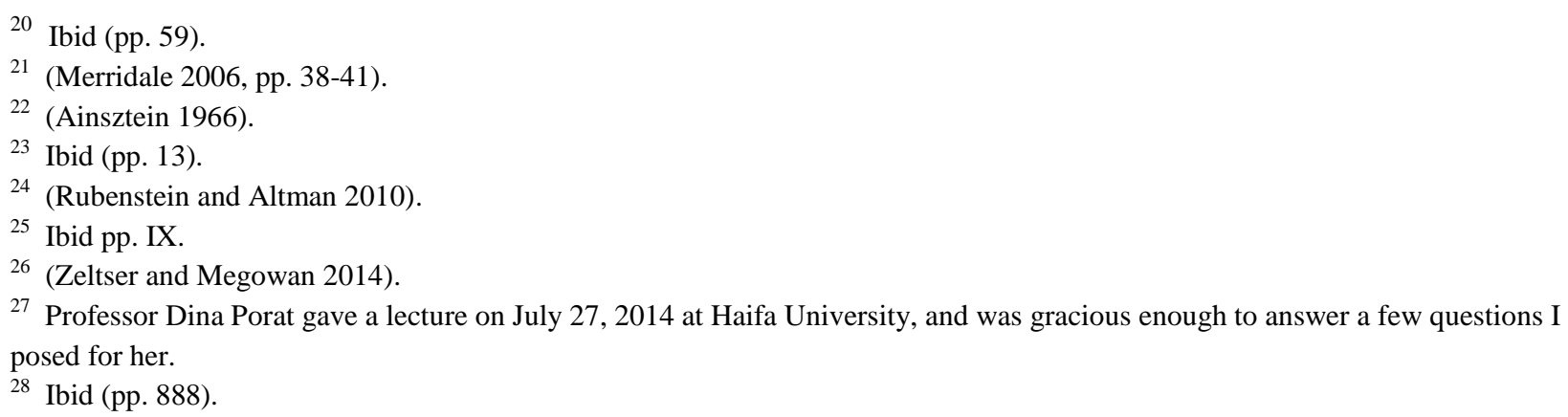


medals, long before scholarship paid any attention to them. ${ }^{29}$ The Der Spiegel article, mentioned in the introduction, ${ }^{30}$ describes the activities of this group of Soviet Jewish veterans as beginning in the early 1980s. The tale is embroiled in the secretive history of the USSR, whose archives and inner workings have become accessible only after the fall of Communism. Following Dimitri Volkogonov's publication of the Rise and Fall of the Soviet Empire ${ }^{31}$ archivists and researchers began developing the database to serve historiographers. In the 1980s, Prime Minister Begin signed a decree for the creation of a monument to the fallen Jewish Red Army soldier, situated in the main national cemetery on Mt. Herzl. It was observed, "Erecting a monument to Red Army Jewish soldiers next to the graves of Israeli soldiers symbolized the contribution of the veterans, and, indeed the Russian community to the foundation of the Israeli state." ${ }^{32}$

\section{The Stories}

Stories of individual valor of Jewish soldiers have gained recognition only in recent times, and the sacrifices of countless Jewish soldiers have been routinely suppressed in the narratives of most scholarship. ${ }^{33}$ The ones reproduced here are intended to illuminate and breathe life into the above narrative of facts and figures.

\section{Colonel Isaac Graifer: A suitcase always packed in the hallway}

The story of Colonel Isaac Graifer is recounted based on a series of interviews with his daughter in Moscow (via Skype) and his granddaughter in Israel. I am in possession of a large amount of documents detailing his career and personal life, some of which are reproduced at the end of the paper. ${ }^{34}$

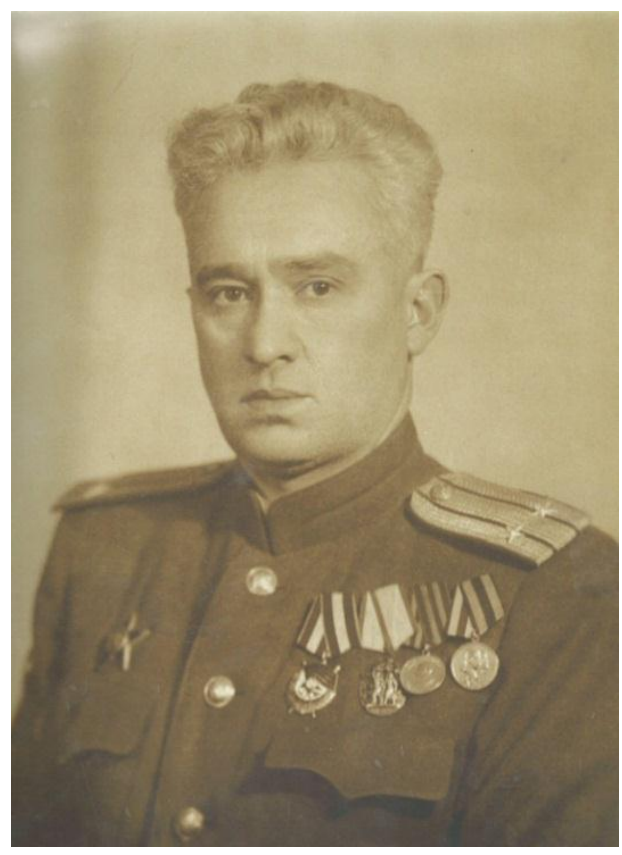

Figure 1. Isaac Graifer in 1948

Isaac Graifer was born in Koryukovka, Chernigov district, Ukraine. In his youth he moved to Baku, Azerbaijan, and enlisted in the army in 1925. The rest of his family remained in Chernigov and perished when the Nazis liquidated the region's Jews, in 1941. Today they are listed in the Yizkor Memorial in Chernigov. During the 1937-38 period he rose rapidly in the army and received a series of promotions, achieving the rank of Commissar. He worked directly under Marshall Vasily Blyukher, as a favorite, and was demoted, but luckily not executed, when Stalin had Blyukher executed in late 1938. He remained in the Red Army, and in 1941-1943 was stationed in the Urals, in charge of the plant that manufactured Katyushas. During these years he went frequently to the front to test the rockets and refine their performance. After a meteoric rise, he was sent to Moscow in July 1944, and became Chief of the Military Building

29 Again, referring to Professor Porat's personal remarks.

30 (Asher 2003, pp. 883-89).

31 (Volkogonov and Shukman 1998).

32 (Roberman 2009, pp. 58-59).

33 (Roberman 2009, pp. 53-56).

34 (Archives 2005-2014). 
Division. In 1947, still in the army, he was demoted but remained in the army, probably because his professional expertise was valuable.
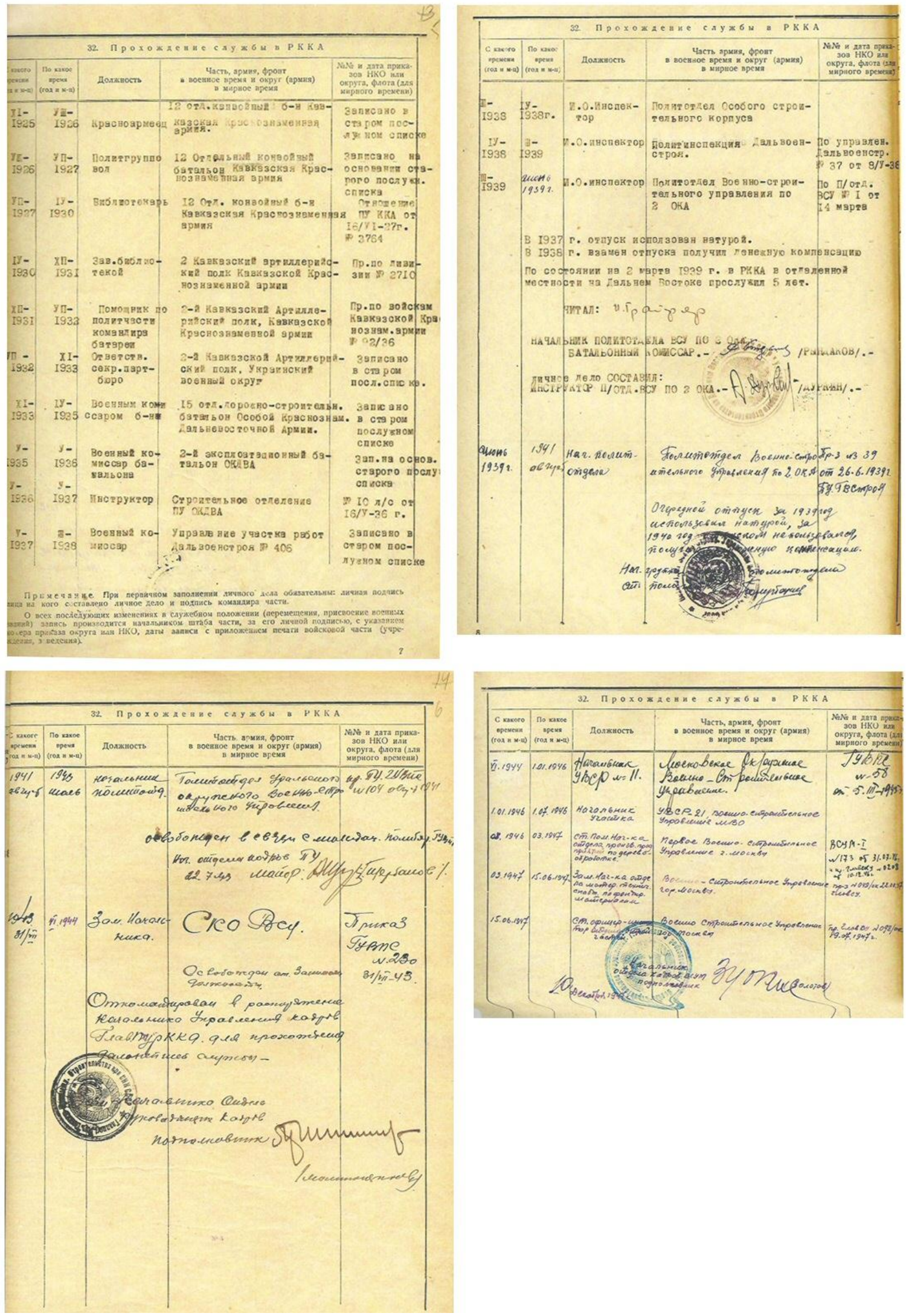
Figure 2. Isaac Graifer: Assignments and Promotions in the Red Army

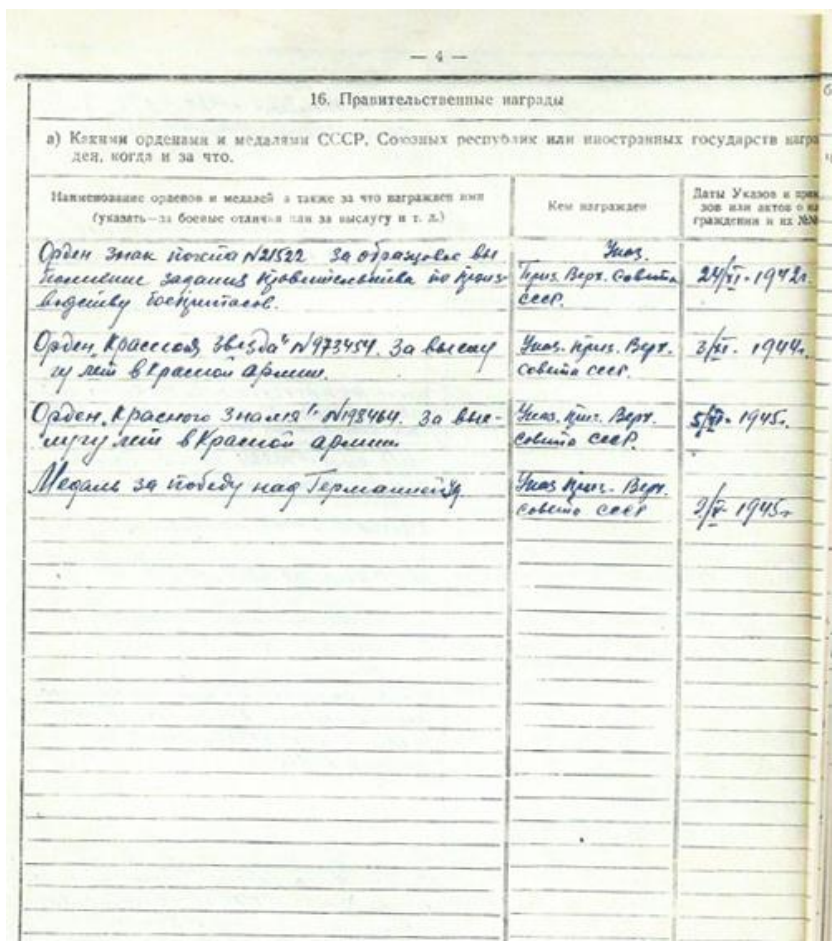

Figure 3. Isaac Graifer: Decorations

When he died in 1949, of a sudden heart attack, he was a full Colonel and was buried with military honors, an event remembered by his children as "quite grand." In the course of his career, he received many important decorations, and although his career had its ups and downs, he survived the purges and remained an officer until his death.

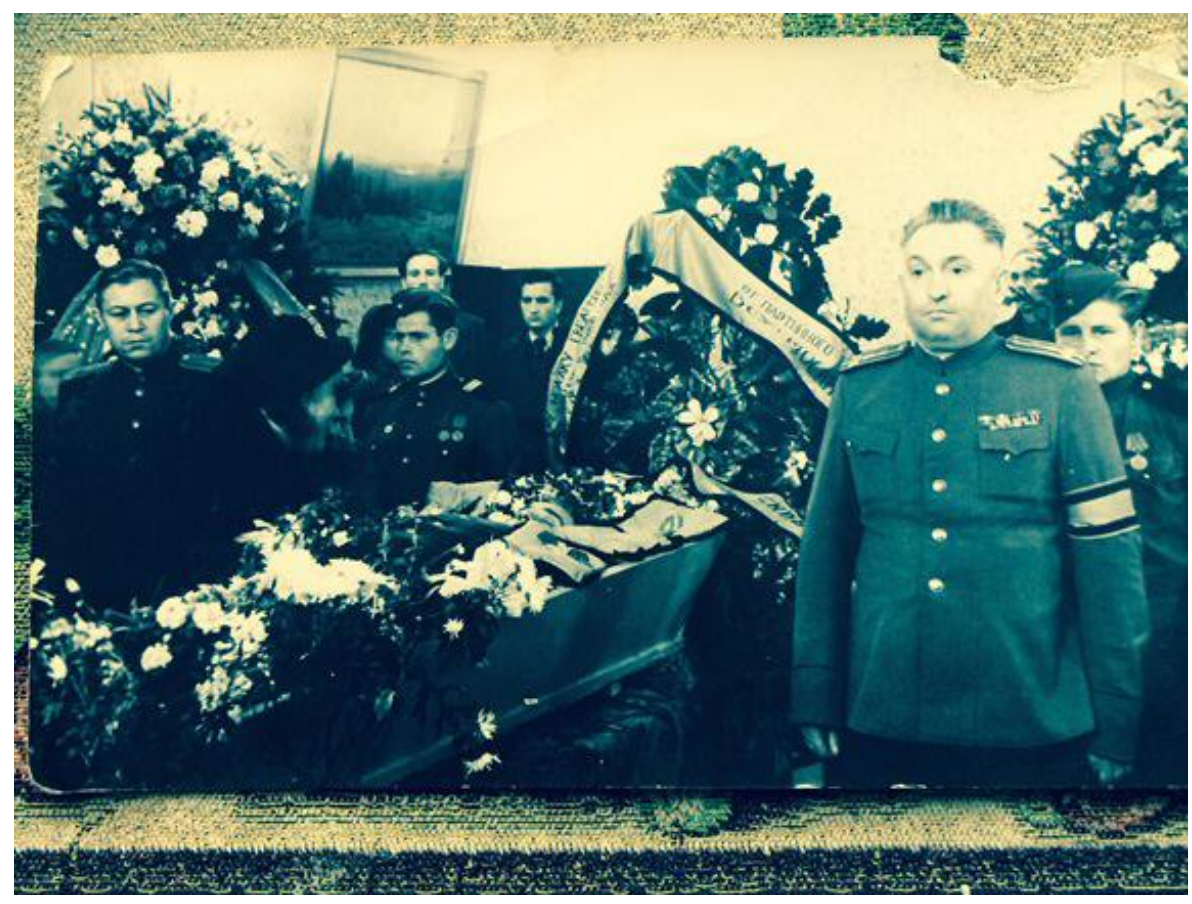


Figure 4. Isaac Graifer: Military Funeral

His daughter recalls that Isaac Graifer never wore civilian clothes and that she never saw him except in uniform. At the same time, there was always a suitcase packed in the hallway, waiting for the eventuality that he would be taken suddenly from his home and family. ${ }^{35}$

\subsection{Abram Inikson: Trumpeter, Jew, and Patriot}

Little is known about Abram Inikson, but the telegram he wrote to Stalin, on July 3rd, 1941, about 10 days after Operation Barbarossa was launched, is a self-explanatory statement of patriotism and admiration for Stalin, sentiments common among Jews during the war period. ${ }^{36}$

\section{Government Telegram Moscow Central Telegraph}

\section{To: Comrade Stalin, Chairman of the Defense Committee}

In response to your speech addressed to the people of the USSR on the third of July, I, a participant in the First World War, dismissed from the military records because of illness, appeal to you to accept me into the ranks of the Red Army, so that I could encourage with my trumpet the valiant divisions of the Red Army for the last decisive battle with the enemy for the Motherland, for honor, for freedom, for Stalin.

\section{Trumpeter of Cavalry Abram Inikson}

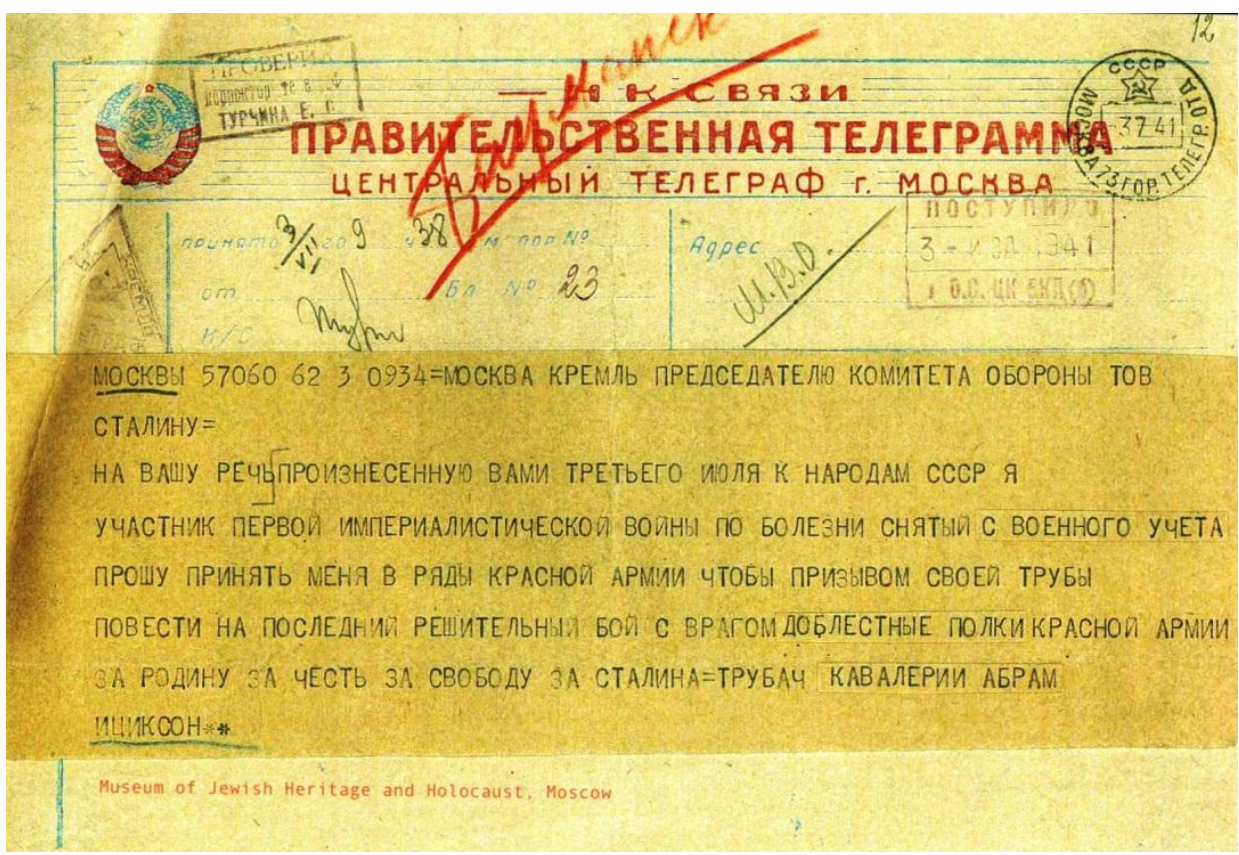

Figure 5. Abram Inikson's telegram to Comrade Stalin

\subsection{Lydia Vladimirovna Litvyak: Flying Ace}

This fighter pilot was romanticized and remembered as the "White Rose of Stalingrad." She holds the record for most kills by a female fighter pilot in all wars, and was the Soviet Union's first female flying ace. ${ }^{37}$ She was shot down and killed in August of 1943, having left behind an unforgettable mark in the history of Soviet military aviation. On May 6, 1990, USSR President, Mikhail Gorbachev, posthumously awarded Litvyak the Hero of the Soviet Union decoration.

\footnotetext{
35 Based on interviews conducted with Irina Isaacovna Graifer in August 2014, in her Moscow apartment.

36 The original telegram (reproduced at the end of the paper) is found at the Museum of Jewish Heritage and Holocaust (Moscow), in the section of the Holocaust and Jews in the military. This modest collection and exhibit is only a few years old. An interview with one of the three curators revealed that the project is growing, and much new archival material is making its way into the collection.
}

37 (Yenne 2013). 


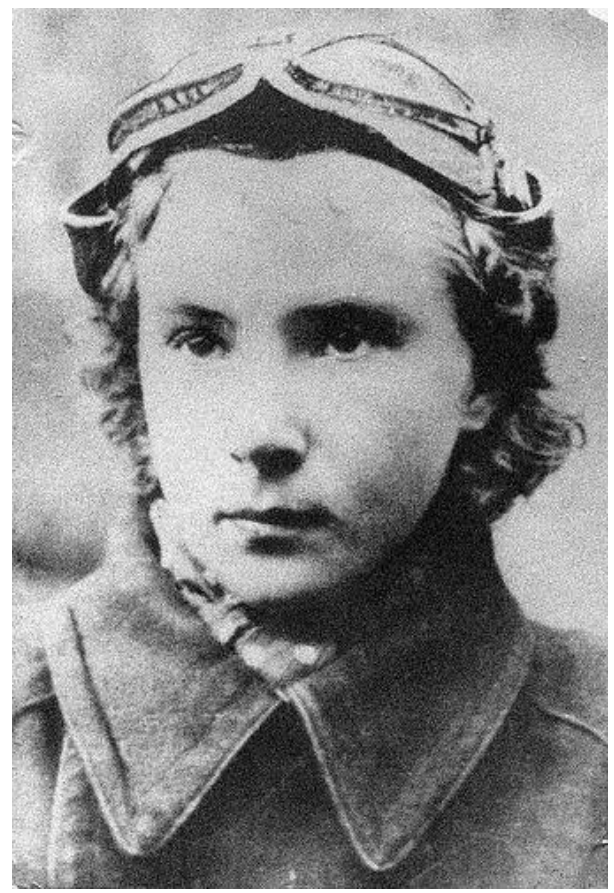

Figure 6. Lydia Vladimirovna Litvyak

\subsection{Abram Gutman: "We had to"}

Abram Gutman describes his actions during the war as a turn of duty: "we had to." What follows is an excerpt from the records of the Balatnik Archives (NYC): "Gutman enlisted in the army in 1940 and was directed to a naval base on the Khanko Peninsula, near the border with Finland. Sirens announced the start of war on June 22, 1941, and Gutman participated in the construction of fortified gun positions and shore barricades, and set up mine fields. He finished the war in Leningrad." 38

I was injured under the following circumstances. We were setting up mines in anticipation of enemy infantry, anti-infantry and anti-tank mines. This was at night. Our platoon commander, Boris Ivanovich Pochkin - I have his photograph - he felt that the work we did wasn't enough, because field mines were covered with crap, so to say, and experienced enemy combat engineers could immediately recognize the mines. He wanted to set up something better. So the improvement consisted of wiring fuses onto the mines. The fuses were very thin wires, practically invisible. If the fuse were touched slightly, the minefield would explode. So to set up the fuses, two units of the platoon had to work on it, the unit under my command and another unit under the command of Otsenko.

We were setting up the mines, and our platoon commander ordered the rest of the soldiers to leave the premises and we remained by ourselves - the platoon commander, Otsenko, and me - so we could finish setting up the fuses. This was a very responsible, complicated task. Most importantly, this task needed lighting, which we didn't have because we were working at night. So if you touched the wire, we knew what would happen. So that's why he ordered everyone except us to leave; we were better trained and more experienced. The second guy, Otsenko, was also educated; he had already graduated from a technical school. I had finished two years of a university program, and he graduated from a technical school. He was older than me. A good guy. He died on the spot.

So naturally we were discovered and [the enemy] immediately began firing at us. What happened was they were using mortars, which blew up our mines. And on top of that, Otsenko must have touched the charge that he was setting up. And so the image, which has stayed with me for the rest of my life, how everything was torn out of here (points to his stomach) and here (points to his head). He was still breathing and blood was spraying out of his head. This image remained with me forever. Obviously, he died on the spot.

My platoon commander was also injured, a serious injury. My injury turned out to be the least critical, which is why I carried my platoon commander out of the trenches, from the place where we were working. Because he

38 (Archives 2005-2014) Gutman was interviewed in Freemont, CA, in 2006. 
was an officer and because his injury was more serious than mine, he was evacuated immediately. I didn't see him after that. Only later did the medic come to me and I was taken out. I was exhausted, all that mud, all that dirt, they had to operate on me three times because of the infection... what is it called... blood infection. I was pretty down. And we were taken to the underground hospital; I was carried in on a stretcher, and brought into the big room. This was an operating room. I saw light, electricity; I hadn't seen electricity in a very long time, all this light! There were many tables, operating tables... and there were women! Beautiful women! When I saw these women, I understood that life was worth living, and I felt good, and I felt sure that I would survive."

\section{Conclusion}

From the October Revolution onward, through Sovietization, Stalinism, WWII, and the Holocaust, serving in the Red Army has been pivotal for the personal history of many Russian Jews. After the collapse of Soviet Communism, this service continued to reverberate individually, and in the collective memory, of Russian Jews. As more and more Jews arrived in Israel, the Jewish Red Army soldier has come to assume a central role in their collective identity, and has become part of the narrative of the State of Israel. Thus, the "migrating past" continues as a present-day cultural dynamic.

\section{Reference}

Ainsztein, Reuben. (1966). The War Record of Soviet Jewry. Jewish Social Studies, 3-24.

Altshuler, Mordechai. Jewish Holocaust Commemoration Activity in the USSR under Stalin.

Altshuler, Mordechai. (1998). Soviet Jewry on the Eve of the Holocaust: A Social and Demographic Profile: Berghahn Books.

Arad, Yitzhak. (2010). In the Shadow of the Red Banner: Soviet Jews in the War Against Nazi Gemany: Gefen Publishing House Ltd.

Archives, Blavatnik. (2005-2014). Video Testimonies: Blavatnik Archives. NYC, NY.

Asher, Harvey. (2003). The Soviet Union, the Holocaust, and Auschwitz. Kritika: Explorations in Russian and Eurasian History, 4(4), 886-912.

Bemporad, Elissa. (2007). The yiddish experiment in soviet minsk. East European Jewish Affairs , 37(1), 91-107.

Clowes, Edith W. (1992). Ideology and Utopia in Recent Soviet Literature, Russian Review, 378-395.

Davis, Mac. (1945). Jews Fight Too!: Jordon Publishing Company.

Gitelman, Zvi. (1990). History, memory and politics: The Holocaust in the Soviet Union. Holocaust and Genocide Studies, 5(1), 23-37.

Gitelman, Zvi Y. (2001). A century of ambivalence: the JeGGws of Russia and the Soviet Union, 1881 to the present: Indiana University Press.

Hundert, Gershon David. (2008). The YIVO Encyclopedia of Jews in Eastern Europe, Yale University Press.

Interviews, Gaifer Family. (2014). Colonel Gaifer a Jew and Soviet Soldier. In NB a manuscripts also exists with complete army records of Colonel Gaifer, edited by Gabriel Mayer. unpublished.

Kaufman, Isidor. (1947). American Jews in World War II: the story of 550,000 fighters for freedom, 2, Dial Press.

Merridale, Catherine. (2006). Ivans war, Life and Death in the Red Army. NY.

Porat, Dina. (2009). The Fall of a Sparrow: The Life and Times of Abba Kovner: Stanford University Press.

Roberman, Sveta. (2007). Commemorative Activities of the Great War and the Empowerment of Elderly Immigrant Soviet Jewish Veterans in Israel. Anthropological Quarterly, 80(4), 1035-1064.

Roberman, Sveta. (2009). From Exclusion to Inclusion: Jewish WWII Soldiers in the Israeli National Narrative. Israel Studies, 14(2), 50-71.

Rubenstein, Joshua, and Ilya Altman. (2010. The unknown black book: the Holocaust in the German-occupied Soviet territories: Indiana University Press.

Snyder, Timothy. (2012). Bloodlands: Europe between Hitler and Stalin: Basic Books.

Sontheimer, Michael. (2005). Jewish Red Army Soldiers Remember WWII, Aus Dem Spiegel.

Tolts, Mark. (1995). Trends in Soviet Jewish demography since the Second World War.

Tolts, Mark. (1997. The interrelationship between emigration and the socio-demographic profile of Russian Jewry. 
Tolts, Mark. (2014). Sources for the Demographic Study of the Jews in the Former Soviet Union, Prepublication Manuscript (This prebublication manuscript was personally shared by the author), 166-177.

Volkogonov, Dmitrii Antonovich, and Harold Shukman. (1998). The Rise and Fall of the Soviet Empire: Political Leaders from Lenin to Gorbachev: HarperCollins.

Yalen, Deborah H. (2011). The Soviet Shtetl: Ideology, Scholarship, Memory.

Yenne, Bill. (2013). The White Rose of Stalingrad: The Real-Life Adventure of Lidiya Vladimirovna Litvyak, the Highest Scoring Female Air Ace of All Time: Osprey Publishing.

Zeltser, Arkadi, and Erina Megowan. (2014). Differing Views among Red Army Personnel about the Nazi Mass Murder of Jews. Kritika: Explorations in Russian and Eurasian History, 15(3), 563-590.

\section{(cc) EY}

This work is licensed under a Creative Commons Attribution 3.0 License. 